\title{
DETERMINING FACTORS ASSOCIATED WITH THE KNOWLEDGE, ATTITUDE AND PRACTICE OF COVID-19 PANDEMIC AMONG MEDICAL STUDENTS IN MALAYSIA
}

\author{
Amirah Azzeri, Muhammad Amalin, Kamaruddin Ezieyan, Zaidi Nurin, Nazri Aina, Ridza Anis, Anuar \\ Balkhis, Affandi Arni, Zuhairi Alia, Rashid Farhan, Ayub Haziq, Rahman Al Azam, Najib Nazdmi, \\ Shamsuddin Syamim, Tengku Amatullah Madeehah Tengku Mohd, Nadeeya 'Ayn Umaisara Mohamad Nor, \\ Mohamed Fakhri Abu Baharin, Nizam Baharom, Mohd Dzulkhairi Mohd Rani, Aza Sherin Mohamad Yusuff, \\ Zairina A Rahman and Hafiz Jaafar
}

Public Health Unit, Department of Primary Health Care, Faculty of Medicine and Health Sciences, Universiti Sains Islam Malaysia, Nilai, Negeri Sembilan, Malaysia

Corresponding author: Mohd Hafiz Bin Jaafar

Email: drhafizjaafar@gmail.com/dr.hafizjaafar@usim.edu.my

\section{ABSTRACT}

The COVID-19 pandemic results in unprecedented impacts globally. Discoveries and knowledge on this pandemic are evolving. A study was conducted to determine factors that could be associated with the knowledge, attitude and practice towards the COVID-19 pandemic among medical students at one of the public universities in Malaysia. A crosssectional study was conducted through an online survey using a set of questionnaires. The questionnaire was adapted and adopted from validated sources. This study found that the scores for knowledge, attitude and practice were high among medical students. Male students had a higher level of knowledge whereas females had a significantly higher level of attitude and practice. For clinical year students, a higher level of knowledge and practice were recorded compared to the pre-clinical year students. The findings from this study could be used to understand the level of knowledge, attitide and practice of COViD-19 among university students and could help in planning for effective awareness campaigns in higher education institution in Malaysia.

Keywords: KAP, COVID-19, Medical Students, Pandemic

\section{INTRODUCTION}

The novel coronavirus disease (COVID-19) is a global health concern. The pandemic is approaching 20 million cases and 734 thousand deaths by early August 2020 (Worldmeter,2020). COVID-19 infection is very contagious and transmissible causing profound social, economic, and political upheaval worldwide. A variety of measures were deployed by governments and public health organizations worldwide to increase awareness, improve knowledge, and strengthen the preventive measures to control COVID-19 transmissions (World Health Organisation,2020 and Centers for Disease Control and Prevention,2019). However, lack of knowledge about COVID-19 transmission, inadequate understanding of the population at risk, and not being attentive to preventive measures are still widespread among regions and populations. As a result, COVID-19 infections keep on spreading and cause profound morbidity and mortality around the world.

Several studies such as Taghrir, Borazjani and Shiraly (2020), Modi et al. (2020), Aker and Midık (2020), Ikhlaq et al (2020) and Alzoubi et al (2020) have been conducted to analyse the level of knowledge, attitude, perceptions, and risk reduction practices of COVID-19 transmission among various population groups. However, researches focussing on medical students are lacking.. Medical students are the future frontliners and they should be equipped with adequate knowledge and exposure to a pandemic and its management ${ }^{1}$. Such studies are critical to provide empirical evidence on interventions and techniques that can be implemented for COVID-19 prevention among medical students' populations. To our knowledge, no study has been published assessing the knowledge, attitude, and practices (KAP) of medical students in Malaysia towards COVID-19. Therefore this study aimed to determine the KAP scores of COVID-19 pandemic and factors associated with the scores among medical students at one of the public universities in Malaysia, Universiti Sains Islam Malaysia (USIM)

\section{METHODOLOGY}

A cross-sectional study design was conducted at the Faculty of Medicine and Health Sciences, USIM through an online survey from 1st of June until the 24th of August 2020. The study participants were all USIM's undergraduate medical students from year 1 until year 6 . A total of 471 USIM's medical students were included in this study. Ethical approval was obtained from USIM Research Ethics Committe (USIM/REC/1020-140)

The questionnaire were drafted in Words format and were converted into Google Form. The link to 
the questionnaire was disseminated through WhatsApp Messenger and reminder messages to fill in the questionnaire were sent daily from 2 nd of July 2020 until 11 th of July 2020. The questionnaire includes questions on sociodemographic data and the contact history of COVID-19. It also contains questions on knowledge, attitude and practice towards COVID19. A questionnaire on knowledge, attitude and practice on COVID-19 was adopted and adapted based on the previous studies. The level of each component was measured by the total scores obtained and categorized accordingly before being analysed. Associations between independent variables (sociodemographic information and contact history of COVID-19) and knowledge, attitude and practice scores towards COVID-19 were analysed through bivariate analysis.

The knowledge part consists of seven questions that focused on four domains (infectivity, testing, treatment and public health measure). One point was given for every correct answer and nil for every incorrect or "not sure" answer. The attitude part consists of 11 questions which were adopted and adapted from previous studies and constructed based on the health belief model (Costa, M. F., 2020) that focused on five different domains; perceived susceptibility, perceived severity, perceived benefit, perceived barrier and perceived response efficacy. A five points Likertscale ranging from "strongly disagree, disagree, neutral, agree to strongly agree" was used. The values ranged from 1-5 or 5-1 respectively depending on the construct of the question (direct or reversed questions). There were 10 questions on the practice part. The scoring was based on five points Likert-scale ranging from "never, rarely, sometimes, often and always". The values also ranged from 1-5 or 5-1 respectively depending on the construct of the question (direct or reversed questions). Overall, the Croanbach's alpha coefficient ranged from 0.707 to 0.790 .

The participant's score was transformed into a percentage by dividing the score by the total score and multiplying the value by 100 . Each KAP scores were categorised accordingly by Bloom's cut-off points which are $\leq 59 \%, 60-79 \%$ and 80 $100 \%$. Knowledge score was categorised into 'Poor', 'Moderate' and 'Good' while the attitude score was categorised into 'Negative', 'Neutral' and 'Positive'. Similarly the practice score was grouped into 'Poor', 'Fair' and 'Good' accordingly (Bloom et al., 1956).

All data were analysed using IBM Statistical Program for Social Sciences (SPSS) application version 25.0. Descriptive analysis was used to describe the socio-demographic characteristics of the sample. The continuous data were presented using Mean (SD) while frequency (percentage) were used to present the categorical data. Independent t-test was conducted to analyse the relationship between gender, level of education and contact history of COVID-19 with knowledge, attitude and practice of COVID-19 pandemic. Meanwhile, for the relationship between year of study and household income with knowledge, attitude and practice of COVID-19 pandemic, Analysis of Variance (ANOVA) was used. The knowledge, attitude and practice categories and factors associated with the scores were analysed using the chi-square test separately.

\section{RESULTS}

\section{Sociodemographic characteristics of study participants}

A total of 471 medical students completed the questionnaire and were included in the study. The response rate was $99.16 \%$ with four nonrespondents. The sociodemographic data are shown in Table 1. There was a higher number of female respondents with a frequency of $334(71 \%)$ compared to male respondents that consist of 137 (29\%). Among them, a total of $95(20.1 \%), 81$ (17.2\%), 87 (18.5\%), 43 (9.1\%), 82 (17.4\%), 83 $(17.6 \%)$ students were from the first, second, third, fourth, fifth and sixth year respectively. Most of the respondents were from urban areas $(n=297,63.1 \%)$. The majority of the respondents were in the $M 40$ group $(n=188,40 \%)$, followed by T20 group $(n=169,36 \%)$ and B40 group $(n=109,24 \%)$. About $369(78.3 \%)$ students stayed with five and more people. Only $4(0.9 \%)$ students had a contact history with a COVID-19 patient. The majority of the respondents $(n=429,91.1 \%)$ had never been tested for COVID-19.

\section{Knowledge towards COVID-19 pandemic}

The majority of the medical students scored correctly in the items under the infectivity and public health measure which were $95.5 \%$ and 98.7\% respectively. The majority of them answered wrongly on questions regarding testing and treatment; only $29.3 \%$ of the students knew that SARS-CoV-2 antibody tests are not the gold standard for diagnosis of COVID-19 infection, and only $22.1 \%$ knew that routine use of systemic corticosteroids for the treatment of SARS-CoV- 2 is not recommended. There was a significant difference between knowledge with gender, year of study and level of education. Male scored higher in knowledge compared to female. Clinical year students also had higher knowledge scores (38.5\%) compared to preclinical year students (12.9\%). There was no significant difference between knowledge with household income and history of COVID-19 contact. 
Table 1: Frequency and percentage distribution of sociodemographic characteristics of study participants $(n=471)$

\begin{tabular}{|c|c|c|c|}
\hline Variables & & $\begin{array}{c}\text { Frequency } \\
\text { (n) }\end{array}$ & $\begin{array}{c}\text { Percentage } \\
\text { (\%) }\end{array}$ \\
\hline \multirow[t]{2}{*}{ Gender } & Male & 137 & 29 \\
\hline & Female & 334 & 71 \\
\hline \multirow{6}{*}{ Year of study } & 1 & 95 & 20.1 \\
\hline & 2 & 81 & 17.2 \\
\hline & 3 & 87 & 18.5 \\
\hline & 4 & 43 & 9.1 \\
\hline & 5 & 82 & 17.4 \\
\hline & 6 & 83 & 17.6 \\
\hline \multirow{2}{*}{ Geographical area } & Urban & 297 & 63.1 \\
\hline & Rural & 174 & 36.9 \\
\hline \multirow{3}{*}{ Household income } & $\leq \mathrm{RM} 4360(\mathrm{~B} 40)$ & 109 & 24.0 \\
\hline & RM4361- RM9619 (M40) & 188 & 40.0 \\
\hline & $>$ RM9619 (T20) & 169 & 36.0 \\
\hline \multirow[t]{4}{*}{ Household size } & Alone & 1 & 0.2 \\
\hline & 1-2 people & 4 & 0.8 \\
\hline & 3-4 people & 97 & 20.6 \\
\hline & 5 or more people & 369 & 78.3 \\
\hline History of contact with & Close family & 1 & 0.2 \\
\hline \multirow[t]{5}{*}{ COVID-19 patient } & Relatives & 3 & 0.6 \\
\hline & Friends & 4 & 0.9 \\
\hline & Neighbour & 4 & 0.9 \\
\hline & Friends of friend & 1 & 0.2 \\
\hline & None & 458 & 97.2 \\
\hline \multirow[t]{2}{*}{ Tested for COVID-19 } & Yes & 42 & 8.9 \\
\hline & No & 429 & 91.1 \\
\hline \multirow[t]{15}{*}{ Source of information } & Newspaper & 102 & 21.7 \\
\hline & News magazine & 3 & 8.1 \\
\hline & Radio News & 137 & 29.1 \\
\hline & Television News & 384 & 81.5 \\
\hline & Twitter & 270 & 57.3 \\
\hline & Instagram & 253 & 53.7 \\
\hline & Facebook & 194 & 41.2 \\
\hline & Youtube & 178 & 37.4 \\
\hline & Tiktok & 33 & 7.0 \\
\hline & Whatapps & 243 & 51.6 \\
\hline & Telegram & 209 & 44.4 \\
\hline & Wechat & 1 & 0.2 \\
\hline & Google & 255 & 54.1 \\
\hline & Official government website & 28 & 50.9 \\
\hline & Friends and family & 27 & 58.8 \\
\hline
\end{tabular}

\section{Attitude towards COVID-19 pandemic}

Most of the respondents had a positive attitude towards the COVID-19 pandemic. The majority of the students strongly agreed that movement control order and social distancing could reduce the spread of COVID-19 infection. A total of $83.7 \%$ $(n=395)$ agreed that they were able to spend quality time with family, and $77.0 \% \quad(n=363)$ believed that they can protect their family from COVID-19 if they were to be quarantined away from them. There was a significant difference between attitude and gender with a p-value of 0.02 . Females perceived more positive attitude compared to male students. No significant difference between attitude score with the year of study, level of education, household income and contact history of COVID-19.

\section{Practice towards COVID-19 pandemic}

Overall, students had good practices toward the prevention of COVID-19. Majority respondents always wore face masks $(\mathrm{n}=289,61.3 \%)$, maintained social distancing $(n=277,48.1 \%)$ and kept themselves updated to latest COVID-19 information $(n=182,38.6 \%)$. There was a significant difference between practice and gender with a $\mathrm{p}$-value of 0.001 . Female students had good practice towards COVID-19 prevention compared to male students. The mean practice score of female students were also higher than male students. There was also a significant difference between practice with the year of study, where a higher mean score was found in clinical year students. However, there was no statistically significant difference in practice score with household income and history of COVID-19 contact. Table 2,3,4 and 5 elaborated on the relationships between independent variables and knowledge, attitude and practicescore categories. 
Table 2: Bivariate analysis of knowledge, attitude and practice toward COVID-19 pandemic

\begin{tabular}{|c|c|c|c|c|c|c|c|c|}
\hline \multirow{2}{*}{ Variable } & \multirow{2}{*}{ Characteristic } & \multirow{2}{*}{ No. (\%) } & \multicolumn{2}{|c|}{ Knowledge } & \multicolumn{2}{|c|}{ Attitude } & \multicolumn{2}{|c|}{ Practice } \\
\hline & & & Mean (SD) & $\mathrm{p}$-value & Mean (SD) & $\mathrm{p}$-value & Mean (SD) & $\begin{array}{c}\text { p- } \\
\text { value }\end{array}$ \\
\hline \multirow[t]{2}{*}{ Gender } & Male & $137(29.1)$ & $4.92(1.176)$ & 0.017 & $42.71(7.979)$ & 0.020 & $\begin{array}{r}38.20 \\
(5.882)\end{array}$ & 0.001 \\
\hline & Female & 334 (70.9) & 4.64 (1.099) & & $44.41(6.771)$ & & $\begin{array}{r}39.87 \\
(4.773)\end{array}$ & \\
\hline \multirow[t]{6}{*}{$\begin{array}{l}\text { Year of } \\
\text { study }\end{array}$} & Year 1 & $95(20.2)$ & 4.12 (1.009) & $<0.001$ & $43.81(8.053)$ & 0.542 & $\begin{array}{r}39.87 \\
(5.648)\end{array}$ & 0.026 \\
\hline & Year 2 & 81 (17.2) & 4.21 (1.057) & & $42.71(6.684)$ & & $\begin{array}{r}37.85 \\
(4.640)\end{array}$ & \\
\hline & Year 3 & 87 (18.5) & $4.78(0.920)$ & & $43.76(6.876)$ & & $\begin{array}{r}38.77 \\
(5.057)\end{array}$ & \\
\hline & Year 4 & $43(9.1)$ & $5.23(0.781)$ & & $45.09(7.892)$ & & $\begin{array}{r}39.70 \\
(6.124)\end{array}$ & \\
\hline & Year 5 & $82(17.4)$ & $5.13(1.097)$ & & 44.37 (7.147) & & $\begin{array}{r}40.23 \\
(5.063)\end{array}$ & \\
\hline & Year 6 & $83(17.6)$ & 5.20 (1.187) & & $44.31(6.535)$ & & $\begin{array}{r}39.38 \\
(4.487)\end{array}$ & \\
\hline \multirow[t]{2}{*}{$\begin{array}{l}\text { Level of } \\
\text { education }\end{array}$} & Preclinical & $263(55.8)$ & 4.37 (1.036) & $<0.001$ & $43.46(7.259)$ & 0.119 & $\begin{array}{r}38.89 \\
(5.206)\end{array}$ & 0.018 \\
\hline & Clinical & $208(44.2)$ & $5.18(1.075)$ & & $44.50(7.045)$ & & $\begin{array}{r}40.02 \\
(5.065)\end{array}$ & \\
\hline \multirow[t]{3}{*}{$\begin{array}{l}\text { Household } \\
\text { income }\end{array}$} & B40 & 109 (23.4) & $4.90(1.154)$ & 0.057 & $44.00(7.192)$ & 0.068 & $\begin{array}{r}39.40 \\
(4.957)\end{array}$ & 0.857 \\
\hline & M40 & $188(40.3)$ & $4.78(1.066)$ & & $44.74(6.893)$ & & $\begin{array}{r}39.55 \\
(4.964)\end{array}$ & \\
\hline & T20 & 169 (35.9) & 4.59 (1.115) & & $42.98(7.437)$ & & $\begin{array}{r}39.25 \\
(5.517)\end{array}$ & \\
\hline $\begin{array}{l}\text { History of } \\
\text { COVID-19 }\end{array}$ & Yes & $13(2.8)$ & $4.62(0.961)$ & 0.720 & $40.08(8.005)$ & 0.050 & $\begin{array}{r}36.85 \\
(5.713)\end{array}$ & 0.072 \\
\hline contact & No & $458(97.2)$ & 4.73 (1.133) & & $44.02(7.130)$ & & $\begin{array}{r}39.46 \\
(5.142)\end{array}$ & \\
\hline
\end{tabular}

Table 3: Factors associated with knowledge towards COVID-19 pandemic among study participants

\begin{tabular}{|c|c|c|c|c|c|c|}
\hline \multirow{2}{*}{ Variable } & \multirow{2}{*}{ Characteristic } & \multicolumn{3}{|c|}{ Knowledge } & \multirow{2}{*}{$\mathrm{X}^{2}$} & \multirow{2}{*}{$\mathrm{p}$-value } \\
\hline & & Poor & Moderate & Good & & \\
\hline Gender & $\begin{array}{c}\text { Male } \\
\text { Female }\end{array}$ & $\begin{array}{r}46(33.6 \%) \\
147(44.0 \%)\end{array}$ & $\begin{array}{r}48(35.0 \%) \\
116(34.7 \%)\end{array}$ & $\begin{array}{l}43(31.4 \%) \\
71(21.3 \%)\end{array}$ & 6.70 & 0.035 \\
\hline Year of study & $\begin{array}{l}\text { Year } 1 \\
\text { Year } 2 \\
\text { Year } 3 \\
\text { Year } 4 \\
\text { Year } 5 \\
\text { Year } 6\end{array}$ & $\begin{array}{r}63(66.3 \%) \\
51(63.0 \%) \\
31(35.6 \%) \\
6(14.0 \%) \\
20(24.4 \%) \\
22(26.5 \%)\end{array}$ & $\begin{array}{ll}23 & (24.2 \%) \\
22 & (27.2 \%) \\
39 & (44.8 \%) \\
24 & (55.8 \%) \\
30 & (36.6 \%) \\
26 & (31.3 \%)\end{array}$ & $\begin{array}{r}9(9.5 \%) \\
8(9.9 \%) \\
17(19.5 \%) \\
13(30.2 \%) \\
32(39.0 \%) \\
35(42.2 \%)\end{array}$ & 90.53 & $<0.001$ \\
\hline $\begin{array}{l}\text { Level of } \\
\text { education }\end{array}$ & $\begin{array}{c}\text { Preclinical } \\
\text { Clinical }\end{array}$ & $\begin{array}{r}145(55.1 \%) \\
46(23.1 \%)\end{array}$ & $\begin{array}{l}84(31.9 \%) \\
80(38.5 \%)\end{array}$ & $\begin{array}{l}34(12.9 \%) \\
80(38.5 \%)\end{array}$ & 61.83 & $<0.001$ \\
\hline $\begin{array}{l}\text { Household } \\
\text { income }\end{array}$ & $\begin{array}{l}\text { B40 } \\
\text { M40 }\end{array}$ & $\begin{array}{l}35(32.1 \%) \\
75(39.9 \%)\end{array}$ & $\begin{array}{l}41(37.6 \%) \\
69(36.7 \%)\end{array}$ & $\begin{array}{l}33(30.3 \%) \\
44(23.4 \%)\end{array}$ & 7.13 & 0.129 \\
\hline & $\mathrm{T} 20$ & 80 (47.3\%) & 53 (31.4\%) & $36(21.3 \%)$ & & \\
\hline $\begin{array}{l}\text { History of } \\
\text { COVID-19 } \\
\text { contact }\end{array}$ & Yes & 7 (53.8\%) & $3(23.1 \%)$ & $\begin{array}{r}3(23.1 \%) \\
111(24.2 \%)\end{array}$ & 1.08 & 0.584 \\
\hline
\end{tabular}


Table 4: Factors associated with attitude towards COVID-19 pandemic among study participants

\begin{tabular}{|c|c|c|c|c|c|c|}
\hline \multirow{2}{*}{ Variable } & \multirow{2}{*}{ Characteristic } & \multicolumn{3}{|c|}{ Attitude } & \multirow{2}{*}{$x^{2}$} & \multirow{2}{*}{$\mathrm{p}$-value } \\
\hline & & Negative & Neutral & Positive & & \\
\hline \multirow[t]{2}{*}{ Gender } & Male & $9(6.6 \%)$ & $37(27.0 \%)$ & $91(66.4 \%)$ & 2.09 & 0.351 \\
\hline & Female & $33(9.9 \%)$ & $100(29.9 \%)$ & $201(60.2 \%)$ & & \\
\hline \multirow[t]{6}{*}{ Year of study } & Year 1 & 7 (7.4\%) & 28 (29.5\%) & $60(63.2 \%)$ & 8.62 & 0.569 \\
\hline & Year 2 & $6(7.4 \%)$ & 25 (30.9\%) & $60(63.2 \%)$ & & \\
\hline & Year 3 & $8(9.2 \%)$ & 28 (32.2\%) & $51(58.6 \%)$ & & \\
\hline & Year 4 & $4(9.3 \%)$ & 9 (20.9\%) & $30(69.8 \%)$ & & \\
\hline & Year 5 & $9(11.0 \%)$ & $30(36.6 \%)$ & 43 (52.4\%) & & \\
\hline & Year 6 & $8(9.6 \%)$ & 17 (20.5\%) & $58(69.9 \%)$ & & \\
\hline \multirow{2}{*}{$\begin{array}{l}\text { Level of } \\
\text { education }\end{array}$} & Preclinical & $21(8.0 \%)$ & $81(30.8 \%)$ & $161(61.2 \%)$ & 1.239 & 0.538 \\
\hline & Clinical & $21(10.1 \%)$ & $56(26.9 \%)$ & $132(63.0 \%)$ & & \\
\hline \multirow{3}{*}{$\begin{array}{l}\text { Household } \\
\text { income }\end{array}$} & B40 & $12(11.0 \%)$ & $31(28.4 \%)$ & $66(60.6 \%)$ & 1.33 & 0.856 \\
\hline & M40 & 14 (7.4\%) & 54 (28.7\%) & $120(63.8 \%)$ & & \\
\hline & $\mathrm{T} 20$ & $16(9.5 \%)$ & $51(30.1 \%)$ & $102(60.4 \%)$ & & \\
\hline \multirow{2}{*}{$\begin{array}{l}\text { History of } \\
\text { COVID-19 } \\
\text { contact }\end{array}$} & Yes & 1 (7.7\%) & $2(15.4 \%)$ & $10(76.9 \%)$ & 1.37 & 0.505 \\
\hline & No & $41(9.0 \%)$ & $135(29.5 \%)$ & $282(61.5 \%)$ & & \\
\hline
\end{tabular}

Table 5. Factors associated with practice towards COVID-19 pandemic among study participants

\begin{tabular}{|c|c|c|c|c|c|c|}
\hline \multirow{2}{*}{ Variable } & \multirow{2}{*}{ Characteristic } & \multicolumn{3}{|c|}{ Practice } & \multirow{2}{*}{$X^{2}$} & \multirow{2}{*}{$\mathrm{p}$-value } \\
\hline & & Poor & Fair & Good & & \\
\hline \multirow[t]{2}{*}{ Gender } & Male & 7 (5.1\%) & 77 (56.2\%) & 53 (38.7\%) & 14.76 & 0.001 \\
\hline & Female & $4(1.2 \%)$ & $146(43.7 \%)$ & $184(55.1 \%)$ & & \\
\hline \multirow[t]{6}{*}{ Year of study } & Year 1 & $3(3.2 \%)$ & 38 (40.0\%) & 54 (56.8\%) & 15.05 & 0.130 \\
\hline & Year 2 & $1(1.2 \%)$ & $51(63.0 \%)$ & $29(35.8 \%)$ & & \\
\hline & Year 3 & $4(4.6 \%)$ & $41(47.1 \%)$ & $42(48.3 \%)$ & & \\
\hline & Year 4 & $1(2.3 \%)$ & 18 (41.9\%) & 24 (55.8\%) & & \\
\hline & Year 5 & $2(2.4 \%)$ & 37 (45.1\%) & 43 (52.4\%) & & \\
\hline & Year 6 & $0(0.0 \%)$ & $38(45.8 \%)$ & 45 (54.2\%) & & \\
\hline \multirow{2}{*}{$\begin{array}{l}\text { Level of } \\
\text { education }\end{array}$} & Preclinical & $8(3.0 \%)$ & $130(49.4 \%)$ & $125(47.5 \%)$ & 2.740 & 0.254 \\
\hline & Clinical & $3(1.4 \%)$ & 93 (44.7\%) & $112(53.8 \%)$ & & \\
\hline \multirow{3}{*}{$\begin{array}{l}\text { Household } \\
\text { income }\end{array}$} & B40 & $1(0.9 \%)$ & 52 (47.7\%) & 56 (51.4\%) & 2.37 & 0.668 \\
\hline & M40 & $4(2.2 \%)$ & $86(45.7 \%)$ & 81 (52.1\%) & & \\
\hline & $\mathrm{T} 20$ & $6(3.6 \%)$ & 81 (47.9\%) & 82 (48.5\%) & & \\
\hline \multirow{2}{*}{$\begin{array}{l}\text { History of } \\
\text { COVID-19 } \\
\text { contact }\end{array}$} & Yes & $0(0.0 \%)$ & 9 (69.2\%) & $4(30.8 \%)$ & 2.68 & 0.262 \\
\hline & No & $11(2.4 \%)$ & $214(46.7 \%)$ & 233 (50.9\%) & & \\
\hline
\end{tabular}




\section{DISCUSSION}

The knowledge, attitude and practices scores on COVID-19 reflect the level of comprehension and readiness of the students towards the pandemic. Study on KAP provides baseline information and the magnitude of understanding about this pandemic from student's perspective. Assessing the KAP score would be helpful planning for effective awareness campaigns in higher education institution in Malaysia.

In this study, males recorded a higher level of knowledge towards COVID-19 compared to females. The main source of knowledge among male students was from social media (Alzoubi et al., 2020 and Hussain et al., 2020). This observation could be due to the fact that nowadays, younger generations were more interested in incorporating social media into their studying with the preference was dominant in male as compared to female. Based on a study by Alnjadat et al (2019), males significantly spent more time on social media than females and this might give them more opportunities to gain more knowledge regarding COVID-19 while they were surfing through social media ${ }^{3}$. It was also supported by Odell et al (2000) which showed that males spent more time on the internet to search for news and help them to keep up to date with current issues such as COVID-19 pandemics ${ }^{4}$.

This study also found that females had significantly higher mean scores on attitude and practice as compared to males. In terms of attitude, females were believed to possess a more positive attitude than males, which was consistent with a study in China that showed females always think rationally and protect themselves ${ }^{1}$. The result of the study also revealed that females had higher means scores on practice compared to males. Few other studies also reported that women were superior to men in terms of the practice (hand hygiene, wearing a mask) related to infectious diseases ${ }^{5-7}$. Apart from that, based on the previous study regarding H1N1 influenza infection in Hong Kong, it was found that male participants tend to perceive the overall severity of the illness to be lower and believed that the outbreak had "no impact" or "only a minor impact" on their daily life ${ }^{8}$. In another study, it was reported that men "tend to downplay the risk and are resistant to risk reduction policies," which is problematic during efforts to promote social distancing and other pandemic restrictions ${ }^{9}$.

Apart from gender, the level of knowledge and practice also differed between the year of studies. Clinical year students (fourth until sixth year) had a higher level of knowledge and practice compared to pre-clinical year students (first until third year). This could have resulted from their training in clinical medicine in which helps to retain their theoretical knowledge learned during the pre-clinical years. These findings were also consistent with a study in Uganda that showed fourth year students were four times more likely to have good knowledge compared to first year counterparts ${ }^{10}$. Besides, clinical year students had experiences in a clinical rotation, which gave them a better understanding of the disease and management of a patient with COVID-19. Moreover, their sense of responsibility as future medical professionals might also drive them to have a more positive attitude and good practice during this pandemic ${ }^{1}$. However, in this study, it was found out that there was no significant relationship between attitude and year of study. These findings were also similar to a study conducted in Uganda ${ }^{10}$. Academic years might not have a great influence on the attitude of the students. Furthermore, they were under the same law regulation in their respective countries, which means that they gained the same exposure during the COVID-19 pandemic.

There was also no significant relationship between knowledge, attitude and practice with household income. This was supported by a study in Philippines whereby a low level of knowledge, attitude and practice was seen among its respondents regardless of their socioeconomic backgrounds ${ }^{11}$ This might be due to a lack of understanding of Non $\neg$ Pharmaceutical Interventions (NPI) strategies which include avoiding confined spaces and large crowds, and practicing social distancing. There was also no significant relationship between knowledge, attitude and practice with contact history shown in this study. However, this result was opposed by Gallè et al (2020) which proved that not knowing someone affected by COVID-19 was associated with a lower level of knowledge, attitude, and practice ${ }^{12}$.

\section{CONCLUSION}

In conclusion, among the factors that contributed to the different levels of knowledge, attitude and practice towards COVID-19 were gender and year of study. Good knowledge, positive attitude and good practice were also recorded by the majority of study population towards COVID-19. These results reflected the efforts made by the local health authorities in providing health information about the COVID-19 to the population. The findings from this study could also be used to plan for awareness campaigns to reduce COVID-19 transmission and spread among the communities.

\section{REFERENCES}

1. Coronavirus Cases: (2020, August 10). Retrieved August 10, 2020, from (Coronavirus Cases)

2. World Health Organization. World Health Organization. 2020. Coronavirus disease (COVID-19) training: Online training. 
https: / /www. who.int/emergencies/diseases /novel-coronavirus-2019/training/onlinetraining.

3. Centers for Disease Control and Prevention. 2019. Coronavirus (COVID-19) https: / / www.cdc.gov/coronavirus/2019ncov/index.html.

4. Taghrir, M. H., Borazjani, R. and Shiraly, R. (2020) 'COVID-19 and Iranian Medical Students; A Survey on Their RelatedKnowledge, Preventive Behaviors and Risk Perception.', Archives of Iranian medicine. Iran, 23(4), pp. 249-254. doi: 10.34172/aim.2020.06.

5. Modi, P. D., Nair, G., Uppe, A., Modi, J., Tuppekar, B., Gharpure, A. S., \& Langade, D. (2020). COVID-19 Awareness Among Healthcare Students and Professionals in Mumbai Metropolitan Region: A Questionnaire-Based Survey. Cureus. doi:10.7759/cureus.7514

6. Aker, S., \& Mıdık, Ö. (2020). The Views of Medical Faculty Students in Turkey Concerning the COVID-19 Pandemic. Journal of Community Health, 45(4), 684-688. doi:10.1007/s10900-020-00841-9

7. Ikhlaq, A. et al. (2020) 'Awareness and Attitude of Undergraduate Medical Students towards 2019-novel Corona virus.', Pakistan Journal of Medical Sciences, 36, p. S--1-- S-5. Available at: http: / / search.ebscohost.com/login.aspx?dir ect $=$ true\&db=a9h\&AN=143046332\&site=ehos t-live.

8. Alzoubi, H., Alnawaiseh, N., Al-Mnayyis, A., Lubad, M. A., Aqel, A., \& Al-Shagahin, H. (2020). COVID-19 - Knowledge, Attitude and Practice among Medical and Non-Medical University Students in Jordan. Journal of Pure and Applied Microbiology, 14(1), 17-24. doi:10.22207/jpam.14.1.04

9. Peng, Y. et al. (2020) 'Knowledge, Attitude and Practice Associated with COVID-19 among University Students : a Cross-Sectional Survey in China', Research Square, (127), pp. 1-24.

10. Bloom, B. S., Engelhart, M. D., Furst, E. J., Hill, W. H., \& Krathwohl, D. R. J. I. (1956). Taxonomy of educational objectives: the classification of educational goals. Handbook I: cognitive domain. New York: David McKay Company.

11. Costa, M. F. (2020). Health belief model for coronavirus infection risk determinants. Revista de Saúde Pública, 54, 47
12.Taber, K. S. (2018). The use of Cronbach's alpha when developing and reporting research instruments in science education. Research in Science Education, 48(6), 12731296.

13.Al-Hazmi, A., Gosadi, I., Somily, A., Alsubaie, S., \& Bin Saeed, A. (2018). Knowledge, attitude and practice of secondary schools and university students toward Middle East Respiratory Syndrome epidemic in Saudi Arabia: A cross-sectional study. Saudi Journal of Biological Sciences, 25(3),

572-577. https://doi.org/10.1016/j.sjbs.2016.01.032

14.Alnjadat, R., Hmaidi, M. M., Samha, T. E., Kilani, M. M., \& Hasswan, A. M. (2019). Gender variations in social media usage and academic performance among the students of University of Sharjah. Journal of Taibah University Medical Sciences, 14(4), 390-394. https: //doi.org/10.1016/j.jtumed.2019.05. 002

15.Alzoubi, H., Alnawaiseh, N., Al-Mnayyis, A., Abu-Lubad, M., Aqel, A., \& Al-Shagahin, H. (2020). Covid-19 - Knowledge, attitude and practice among medical and non-medical university students in Jordan. Journal of Pure and Applied Microbiology, 14(1), 17-24. https: / /doi.org/10.22207/JPAM.14.1.04

16.Gallè, F., Sabella, E. A., Da Molin, G., De Giglio, O., Caggiano, G., Di Onofrio, V., Ferracuti, S., Montagna, M. T., Liguori, G., Orsi, G. B., \& Napoli, C. (2020). Understanding Knowledge and Behaviors Related to CoViD-19 Epidemic in Italian Undergraduate Students: The EPICO Study. International Journal of Environmental Research and Public Health, 17(10). https: / / doi.org/10.3390/ijerph17103481

17.Griffith, D. M., Sharma, G., Holliday, C. S., Enyia, O. K., Valliere, M., Semlow, A. R., Stewart, E. C., \& Blumenthal, R. S. (2020). Men and COVID-19: A biopsychosocial approach to understanding sex differences in mortality and recommendations for practice and policy interventions. In Preventing Chronic Disease (Vol. 17). Centers for Disease Control and Prevention (CDC). https: / / doi.org/10.5888/PCD17.200247

18. Hussain, A., Garima, T., Singh, B. M., Ram, R., \& Tripti, R. P. (2020). Knowledge, attitudes, and practices towards COVID-19 among Nepalese Residents: A quick online cross-sectional survey. Asian Journal of Medical Sciences, 11(3), 6-11. https: //doi.org/10.3126/ajms.v11i3.28485

19.Lau, J. T. F., Griffiths, S., Choi, K. C., \& Tsui, H. Y. (2009). Widespread public 
misconception in the early phase of the H1N1 influenza epidemic. Journal of Infection, 59(2), 122-127. https://doi.org/10.1016/j.jinf.2009.06.004

20.Lau, L. L., Hung, N., Go, D. J., Ferma, J., Choi, M., Dodd, W., \& Wei, X. (2020). Knowledge, attitudes and practices of COVID19 among income-poor households in the Philippines: A cross-sectional study. Journal of Global Health, 10(1). https://doi.org/10.7189/JOGH.10.011007

21.Odell, P. M., Korgen, K. O., Schumacher, P., \& Delucchi, M. (2000). Internet use among female and male college students. Cyberpsychology and Behavior, 3(5), 855862. https: //doi.org/10.1089/1094931005019183 6

22.Olum, R., Kajjimu, J., Kanyike, A. M., Chekwech, G., Wekha, G., Nassozi, D. R., Kemigisa, J., Mulyamboga, P., Muhoozi, 0. K., Nsenga, L., Lyavala, M., Asiimwe, A., \& Bongomin, F. (2020). Perspective of Medical Students on the COVID-19 Pandemic: Survey of Nine Medical Schools in Uganda. JMIR Public Health and Surveillance, 6(2), e19847. https: / /doi.org/10.2196/19847

23.Park, J. H., Cheong, H. K., Son, D. Y., Kim, S. U., \& Ha, C. M. (2010). Perceptions and behaviors related to hand hygiene for the prevention of H1N1 influenza transmission among Korean university students during the peak pandemic period. BMC Infectious Diseases, $10(1), \quad 222$. https://doi.org/10.1186/1471-2334-10-222

24.Peng, Y., Pei, C., Zheng, Y., Wang, J., \& Zhang, K. (2020). Knowledge, Attitude and Practice Associated with COVID-19 among University Students : a Cross-Sectional Survey in China. Research Square, 127, 1-24.

25.Tang, C. S. K., \& Wong, C. Y. (2004). Factors influencing the wearing of facemasks to prevent the severe acute respiratory syndrome among adult Chinese in Hong Kong. Preventive Medicine, 39(6), 1187-1193. https://doi.org/10.1016/j.ypmed.2004.04.0 32 